\title{
Yield of promising lines of peanut and resistance to Aspergillus flavus, aflatoxin, and foliar disease
}

\author{
Joko Purnomo*, Agustina Asri Rahmianna, and Novita Nugrahaeni \\ Indonesian Legumes and Tuber Crops Research Institute (Iletri), Jalan Raya Kendalpayak Km 8 \\ Malang 65101, East Java, Indonesia
}

\begin{abstract}
Peanut is a suitable media for Aspergillus flavus growth that produced secondary metabolite called aflatoxin. One strategy to obtain low A. flavus infection and aflatoxin contamination is growing resistant cultivar. The objective of research was to identify pod yields of genotypes and its resistance to A. flavus and foliar disease, and low aflatoxin contamination. The multi environmental trials were conducted at eight sites. The treatments were 10 promising lines, Kancil and Garuda Biga (check cultivars), and these were arranged in a RBD three replicates in each site. The genotypes were grown under optimal condition. The results indicated the average pod yield of nine lines were significantly $11.2-21.6 \%$ and $23.4-34.8 \%$ higher than those of Kancil and Garuda Biga, respectively. Despite highest pod productivity, G/GH502-00B-600-42-226-19 (3.09 tons) and Mj/G-00b-88495-41 (3.06 tons) had higher score of foliar diseases than those of the check cultivars. Meanwhile MH/IC91278-99C-180-13-74 and LM/IC 87123-93B-32 with 2.91 tons and 2.84 tons ha $\mathrm{A}^{-1}$ had very low aflatoxin contamination $(<0.5 \mathrm{ppb})$ and lower foliar diseases infection than those of check cultivars. MH/IC91278-99C-180-13-74 and LM/IC 87123-93-B-32 therefore were appropriate to be promoted as new cultivars with high pod yield, resistant to foliar disease and A. flavus, and low aflatoxin contamination.
\end{abstract}

\section{Introduction}

Peanut-based food products are very popular in Indonesia. In the last 20 years, the various products have been commercially prepared and marketed both domestic and overseas. The modern types of products, the hygiene process during preparation, the modern and attractive packaging, and the broad consumer targets are components that support peanuts as "branded product" To maintain that status, the peanut-based food industries require raw material with specific characters such as two or three seeded pods, small kernel size, round kernel shape, high oil content, low aflatoxin content, where this last requirement is especially essential for international trade. The industries, therefore, urge the agricultural sector to provide the suitable raw materials both its quality and quantity at the right specification and time. To meet these requirements, peanut breeders have been developing new cultivars with high pod

* Corresponding author: joko.purnomo75@ymail.com 
yield, tolerant to biotic and/or abiotic stresses and quality parameters to meet the market requirements, where these goals are in accordance with global peanut improvement programs $[1,2]$.

In Indonesia, beside low productivity varieties grown by farmers, there are several biotic and abiotic factors that responsible for low national production. The Government has been launching a national program to increase peanut production by improving: cultural practices, pest and disease control, soil nutrient management through fertilization, soil amelioration, seed supply system, developing improved cultivars with high yield productivity and resistant to biotic and/or tolerant abiotic stresses. Being purposed to increase production, the improved varieties with high yield potential were intensively developed by breeders and released by Government.

Peanut in Indonesia is mostly grown in dry season where water availability is very limited during the season. Water shortage at the end of generative growth phase will sharply reduce pod yield as a result of reducing pod and seed weight. The improper seed growth and development resulted immature seeds that is more sensitive to A. flavus infection and aflatoxin contamination. The cultivar or promising lines resistance to aflatoxin contamination combined with pre and postharvest aflatoxin management practices is very essential in reducing aflatoxin contamination [3]. The objective of the experiment was to find out the performance of several promising lines especially on yield productivity, and its resistance to A. flavus infection and aflatoxin contamination.

\section{Materials and methods}

A series of multi environmental trials (MET) was conducted at eight peanut central production areas in the Districts of Jepara (2 sites), Majalengka (2 sites), Tuban (1 site), Pati ( 2 sites), and Malang ( 1 site). In every site, 12 genotypes (10 promising lines: JP/IC87055773-174-117-11; Mj/G-00b-884-95-41; LM/IC87123-93-B2-14; C/G-00B-644-20-175-20; JP/IC8705500B-807-145-36; LM/IC87123-93-B-32; G/GH502-00B-600-42-226-19; MH/ IC91278-99C-180-13-74; GH502/G-00B-600-42-226-12; LM/IC87123-93-B2-25, and 2 check cultivars: Kancil with 1.3-2.4 $\mathrm{t} \mathrm{ha}^{-1}$ of pod productivity, resistant to A. flavus and foliar diseases; Garuda Biga with 1.6-2.5 $\mathrm{t} \mathrm{ha}^{-1}$ of pod productivity, resistant bacterial wilt, moderately resistant to foliar diseases) as treatment and these were arranged in a randomized block design with three replications. The trials were intensively maintained to reach the best yield performance by applying $250 \mathrm{~kg} / \mathrm{ha}$ of NPK fertilizers, two times weeding, pest and disease control, and watering [4].

The severity of leafspot and rust diseases were observed at 80 days after sowing (DAS) based on method developed [5]. At harvest, the observation on vegetative and generative growth components, and yield components were undertaken on 5 sampled plants. Pod yield of every genotype was obtained from $2 \mathrm{~m} \times 5 \mathrm{~m}$ plot size, which then this pod yield was converted in pod yield per hectare.

The infection of $A$. flavus and aflatoxin contamination were observed on seeds obtained from a trial conducted at Muneng Research Station. The similar genotypes and cultural practices as those of MET was applied in this trial. Aspergillus flavus inoculation was carried out to guarantee the presence of abundant population in the geocarphosphere. The inoculation was conducted at 55 DAS by broadcasting the inoculants in the furrows along the plant rows.

The infection of $A$. flavus on both fresh and dry kernels was observed at harvest. A number of 100 seeds were obtained from fresh pods collected from 3 replicates for each treatment. After surface sterilization, those 100 seeds were put in 10 petri dishes that had been prepared with AFPA (Aspergillus flavus and Parasiticus Agar) medium inside or 10 seeds in each petri dish. The presence of $A$. flavus fungus was observed 3-4 days of incubation by observing the 
orange colour mycelia of $A$. flavus at the bottom of AFPA media around the seeds. The number of seeds infected by $A$. flavus was counted to provide the percentage of infectious seeds. The similar procedure was applied for dry seeds with moisture content (MC) around $10 \%$ obtained from dried pods after 5 days of sun-drying. The moisture content of fresh seeds (just after harvest) and dry seeds (after sun-drying) was observed gravimetrically. The level of aflatoxin contamination on fresh and dry seeds was quantified by using a Thin-Layer Chromatography (TLC) method that was undertaken at Service laboratory of SEAMEOBIOTROP in Bogor City of West Java Province, Indonesia.

All data of pod yield and yield components, as well as data on vegetative and generative growth phases were subjected to analysis of variance (RCBD combined over locations) using a statistical program of MStatC 1.4 version developed by Crop and Soil Science Department, Michigan State University. The parameters that were significantly different at $p<0.05$ then subjected to a Duncan's Multiple Rage Test at 5\% level of probability to find out the difference among means of genotypes tested.

\section{Results and discussion}

The mean, minimum, and maximum pod yields and several agronomic components of 12 genotypes averaged from eight growing sites were presented in Table 1. The data indicate that there was significantly difference between maximum and minimum dry pod yield with 3.868 tons and $1.868 \mathrm{tha}^{-1}$ respectively, and $2.78 \mathrm{t} \mathrm{ha}^{-1}$ of average pod yield. The enormous differences were also existing, among others on harvesting age, number of mature pods/plants, plant height, score of leafspot disease, as well as per cent number of mature to total pods/plant (Table 1). These indicate the presence of various plant growths as a response to various site conditions where the genotypes grown. The statistical analysis pointed out the significant effect of location, genotypes, and its interactive effect of location and genotype on dry pod yield, yield components, vegetative growth parameters (data was not presented).

Table 1. Agronomic parameters of ten promising lines and two check cultivars of peanut in eight evaluated locations.

\begin{tabular}{|l|c|c|c|c|}
\hline \multirow{2}{*}{ Parameter } & \multirow{2}{*}{ Mean \pm SE } & \multicolumn{2}{c|}{ Range } & \multirow{2}{*}{ SD } \\
& & Min & Max & \\
\hline Dry pod yield at 10\% moisture content $\left(\mathrm{t} \mathrm{ha}^{-1}\right)$ & $2.78 \pm 0.189$ & 1.868 & 3.868 & 0.535 \\
\hline Harvesting time (days after sowing) $^{*}$ No of mature pods (plant $^{-1}$ ) & $85.6 \pm 1.322$ & 78.8 & 89.0 & 3.741 \\
\hline No of mature pods/total pods (\%) $^{*} 17.5 \pm 1.204$ & 13.7 & 25.6 & 3.407 \\
\hline Mature pod weight (plant $\left.^{-1}\right)$ & $81.7 \pm 1.487$ & 70.9 & 86.2 & 4.205 \\
\hline 100 seeds weight (g) & $26.4 \pm 0.77$ & 23.7 & 29.1 & 2.205 \\
\hline Plant height (cm) & $41.3 \pm 1.34$ & 36.7 & 46.0 & 3.801 \\
\hline Score of leafspots & $37.6 \pm 1.931$ & 27.6 & 47.1 & 5.461 \\
\hline Score of rust & $5.6 \pm 0.246$ & 4.6 & 7.2 & 0.698 \\
\hline
\end{tabular}

Pod yields of all genotypes averaged from eight locations ranged from 2.29 tons to 3.09 $\mathrm{t} \mathrm{ha}^{-1}$ of dry pods where cultivar Garuda Biga produced the lowest pod yield of $2.29 \mathrm{tha}^{-1}$ and genotype GH 7 produced the highest of $3.09 \mathrm{t} \mathrm{ha}^{-1}$ pod yield. The mean pod yield was $2.78 \mathrm{t}$ $\mathrm{ha}^{-1}$, where 10 genotypes and two genotypes gave significantly higher and lower pod yields than that of mean pod yield, respectively. Also, nine genotypes gave higher yields than those of check cultivars (Table 2). Genotype GH 7 had the highest pod yield of $3.09 \mathrm{t} \mathrm{ha}^{-1}$, which was $21.6 \%$ and $34.8 \%$ higher than those of Kancil and Garuda Biga, respectively (Table 2). Six genotypes with productivity of $\geq 2.84$ tons $\mathrm{ha}^{-1}$ of dry pods had no significantly different pod yields to GH 7. All promising lines had higher pod yields than those of check cultivars 
of Kancil (GH 11) and Garuda Biga (GH 12), except one line i.e., GH 10: LM/IC87123-93B2-25 (2.38 $\left.\mathrm{t} \mathrm{ha}^{-1}\right)$ had lower yield than Kancil cultivar that obtained $2.54 \mathrm{t} \mathrm{ha}^{-1}$ of pod yield (Table 2).

Table 2. The average pod yield of ten promising lines and two check cultivars in eight evaluated locations

\begin{tabular}{|c|c|c|c|c|}
\hline \multirow{2}{*}{ Code } & Genotype & \multirow{2}{*}{$\begin{array}{c}\text { Pod yield } \\
\mathbf{( t ~ h a}^{-1} \mathbf{)}\end{array}$} & \multicolumn{2}{|c|}{$\begin{array}{c}\text { Yield difference to the } \\
\text { check cultivar (\%) }\end{array}$} \\
\cline { 4 - 5 } & & & Kancil & Garuda Biga \\
\hline GH 1 & JP/IC87055-773-174-117-11 & $2.94 \mathrm{abc}$ & 15.6 & 28.3 \\
\hline GH 2 & Mj/G-00b-884-95-41 & $3.06 \mathrm{ab}$ & 20.6 & 33.7 \\
\hline GH 3 & LM/IC87123-93-B2-14 & $2.65 \mathrm{~cd}$ & 4.3 & 15.7 \\
\hline GH 4 & C/G-00B-644-20-175-20 & $2.83 \mathrm{bc}$ & 11.2 & 23.4 \\
\hline GH 5 & JP/IC8705500B-807-145-36 & $2.96 \mathrm{ab}$ & 16.6 & 29.4 \\
\hline GH 6 & LM/IC87123-93-B-32 & $2.84 \mathrm{abc}$ & 11.8 & 23.9 \\
\hline GH 7 & G/GH502-00B-600-42-226-19 & $3.09 \mathrm{a}$ & 21.6 & 34.8 \\
\hline GH 8 & MH/IC91278-99C-180-13-74 & $2.91 \mathrm{ab}$ & 14.7 & 27.2 \\
\hline GH 9 & GH502/G-00B-600-42-226-12 & $2.89 \mathrm{abc}$ & 13.7 & 26.1 \\
\hline GH 10 & LM/IC87123-93-B2-25 & $2.38 \mathrm{ef}$ & -6.5 & 3.7 \\
\hline GH 11 & Kancil & $2.54 \mathrm{de}$ & 0.0 & 10.8 \\
\hline GH 12 & Garuda Biga & $2.29 \mathrm{f}$ & -9.9 & 0.0 \\
\hline & Grand mean & 2.78 & - & - \\
\hline & CV (\%) & 5.68 & - & - \\
\hline
\end{tabular}

Notes: Numbers in the same column followed by similar letters did not significantly different based on Duncan Multiple range Test at 0.05 probabilities

The harvesting times ranged from 82 to 87 DAS with an average of 85.7 DAS. The cultivar Garuda Biga had earliest uprooted at 82.9 DAS, and other four genotypes (GH 1, GH 5, GH 9, GH 11) statistically had similar harvesting time to that of Garuda Biga. The rest seven genotypes were harvested later than 85 DAS but before 90 DAS. Based on harvesting time, there was no genotype was classified as extra early maturity with 75-80 days maturity, and medium/intermediate maturity with maturity $90 \leq \mathrm{x} \leq 110$ days [6]. It can be said that our tested genotypes were classified into shorter duration or early maturity genotypes. As of its short maturity, the crop will have less chance to be infested by foliar disease and it will reduce to 1-2 time of fungicide application.

The current study revealed that the maximum and minimum per cent number of mature pods to total pods per plant were $86.2 \%$ and $70.9 \%$ with average of $81.7 \%$ (Table 1 ). Genotype GH 4 had the highest percentage by $82.7 \%$ and GH 1 had the lowest of $78.2 \%$ (Table 3). All these mean that genotypes had more mature pods than those of immature pods in every plant. The percentage number of mature pods to total pods per plant was also known as reproductive efficiency [7]. Furtherly it was informed that Spanish type performed the value of $75.0 \%$ and $77.9 \%$ under rainy and summer season. This report supported our study using Spanish type with highest and lowest percentage by $82.7 \%$ and $78.2 \%$, respectively. The mature pod was identified by the presence of darkening (brownish) colour of the internal pericarp of pods and when $75-80 \%$ of pods of Spanish cultivars show internal pericarp darkening, the crop is ready for harvest [8]. Since all genotypes belong to Spanish type had more than $75 \%$ value, therefore, the genotypes were at right time to harvest.

Number of mature pods per plant ranged from 13-25 pods with average 17 pods. These high numbers of mature pods really support high pod yield per plant as [9-10] reported that pod yield per plant positively correlated with number of mature pods per plant and seed yield per plant. It can be informed that in the current study, there were four genotypes (GH 3, GH 6 , GH 10, and GH 11) with small seed, and the other eight genotypes had medium seed size. 
The genotype had small, medium, and big seed size is when the weight of 100 seeds is $<40$ $\mathrm{g}, 40-50 \mathrm{~g}$, and $>50 \mathrm{~g}$, respectively [11]. (This Paragraphs are too long)

The minimal and maximal average plant height in all tested sites was 27.6 and $47.1 \mathrm{~cm}$, respectively with $37.6 \mathrm{~cm}$ was the average number (Table 2). The tallest genotype of 42.0 $\mathrm{cm}$ belonged to GH 8 and the shortest with $35.0 \mathrm{~cm}$ belonged to GH 5 . The height of GH 5 was similar to that of GH 12 that was the check cultivar of Garuda Biga. According to Nurhalimah et al. [12] that short plant figure was more preferred than that of tall figure because the tall plant was more easily to lodge. Any peanut genotype with at least $50 \mathrm{~cm}$ tall is belong to tall criteria as shown by Sima cultivar with $53.5 \mathrm{~cm}$ tall when grown in wet season [13], Gajah and Sima cultivars with 56.5 and $71.5 \mathrm{~cm}$ grown during wet season [12]. All promising lines were moderately tolerant to the main foliar diseases i.e., leafspot (Cercosporidium personatum) and rust (Puccinia arachidis) $(5.1$ - 6.0) score and 5.5 (4.95.9) for leafspot and rust. Based on yield productivity, vegetative and reproductive growth performance as well as their tolerance to foliar disease infestation, it can be summarized that genotypes GH 2 (Mj/G-00b-884-95-41), GH 5 (JP/IC8705500B-807-145-36), and GH 7 (GH502-00B-600-42-226-19) were prospective to be promoted as new cultivars.

Table 3. Vegetative growth, generative growth, yield components, scores of leafspots and rust diseases of ten promising lines and two check cultivars in eight evaluated locations

\begin{tabular}{|c|c|c|c|c|c|c|c|c|}
\hline Code & $\begin{array}{c}\text { Plant } \\
\text { height } \\
(\mathrm{cm})\end{array}$ & $\begin{array}{c}\text { Harves } \\
\text { ting } \\
\text { time } \\
\text { (DAS) } \\
\end{array}$ & $\begin{array}{c}\text { Dry pod } \\
\text { yield } \\
\text { (g plant } \\
1 \text { ) }\end{array}$ & $\begin{array}{c}\text { No of } \\
\text { mature } \\
\text { pods } \\
\text { plant }^{-1}\end{array}$ & $\begin{array}{c}100 \text { seed } \\
\text { weight } \\
\text { (g) }\end{array}$ & $\begin{array}{c}\text { No of } \\
\text { mature } \\
\text { pods/total } \\
\text { pods }(\%)\end{array}$ & $\begin{array}{c}\text { Score of } \\
\text { leafspots } \\
\text { at } 80 \\
\text { DAS*) }\end{array}$ & $\begin{array}{c}\begin{array}{c}\text { Score } \\
\text { of rust } \\
\text { at } 80 \\
\text { DAS*) }\end{array} \\
\end{array}$ \\
\hline GH 1 & $37.1 \mathrm{cde}$ & $85.5 \mathrm{ab}$ & $27.4 \mathrm{bcd}$ & $20.0 \mathrm{f}$ & $40.2 \mathrm{cde}$ & 78.2 & $5.3 \mathrm{~cd}$ & $4.9 \mathrm{c}$ \\
\hline GH 2 & $35.3 \mathrm{efg}$ & $86.8 \mathrm{a}$ & $29.3 \mathrm{ab}$ & $22.5 \mathrm{abcd}$ & $45.4 \mathrm{a}$ & 80.5 & $5.7 \mathrm{ab}$ & $5.7 \mathrm{ab}$ \\
\hline GH 3 & $39.3 \mathrm{~b}$ & $87.5 \mathrm{a}$ & $24.8 \mathrm{cde}$ & $21.0 \mathrm{def}$ & $36.8 \mathrm{e}$ & 81.7 & $5.9 \mathrm{ab}$ & $5.7 \mathrm{ab}$ \\
\hline GH 4 & $36.1 \mathrm{defg}$ & $85.6 \mathrm{a}$ & $24.7 \mathrm{cde}$ & $23.7 \mathrm{ab}$ & $43.5 \mathrm{abc}$ & 82.7 & $5.7 \mathrm{ab}$ & $5.6 \mathrm{ab}$ \\
\hline GH 5 & $35.0 \mathrm{fg}$ & $84.8 \mathrm{ab}$ & $27.0 \mathrm{bcd}$ & $24.0 \mathrm{a}$ & $44.3 \mathrm{ab}$ & 80.2 & $5.9 \mathrm{ab}$ & $5.8 \mathrm{ab}$ \\
\hline GH 6 & $39.5 \mathrm{~b}$ & $86.0 \mathrm{a}$ & $23.1 \mathrm{de}$ & $21.1 \mathrm{def}$ & $36.3 \mathrm{e}$ & 80.1 & $5.7 \mathrm{ab}$ & $5.4 \mathrm{~b}$ \\
\hline GH 7 & $37.8 \mathrm{bcd}$ & $85.7 \mathrm{a}$ & $28.0 \mathrm{bc}$ & $21.7 \mathrm{cdef}$ & $42.7 \mathrm{abc}$ & 80.7 & $6.0 \mathrm{a}$ & $5.8 \mathrm{a}$ \\
\hline GH 8 & $42.0 \mathrm{a}$ & $86.4 \mathrm{a}$ & $26.3 \mathrm{~b}-\mathrm{e}$ & 22.0 bcde & $40.9 \mathrm{bcd}$ & 81.2 & $5.1 \mathrm{~d}$ & $4.9 \mathrm{c}$ \\
\hline GH 9 & $37.0 \mathrm{cdef}$ & $85.2 \mathrm{ab}$ & $31.8 \mathrm{a}$ & $23.6 \mathrm{abc}$ & $42.9 \mathrm{abc}$ & 81.6 & $5.7 \mathrm{bc}$ & $5.8 \mathrm{ab}$ \\
\hline GH 10 & $38.3 \mathrm{bc}$ & $86.6 \mathrm{a}$ & $25.1 \mathrm{~b}-\mathrm{e}$ & $20.9 \mathrm{ef}$ & $37.7 \mathrm{de}$ & 80.3 & $5.7 \mathrm{ab}$ & $5.5 \mathrm{ab}$ \\
\hline Kancil & $39.9 \mathrm{~b}$ & $85.0 \mathrm{ab}$ & $22.8 \mathrm{e}$ & 20.0 ef & 39.9 cde & 78.8 & $5.7 \mathrm{bc}$ & $5.4 \mathrm{ab}$ \\
\hline $\begin{array}{c}\text { Garuda } \\
\text { Biga }\end{array}$ & $34.6 \mathrm{~g}$ & $82.9 \mathrm{~b}$ & $26.4 \mathrm{~b}-\mathrm{e}$ & $20.7 \mathrm{def}$ & $45.6 \mathrm{a}$ & 80.4 & $5.7 \mathrm{ab}$ & $5.5 \mathrm{ab}$ \\
\hline Mean & 37.6 & 85.6 & 26.4 & 21.7 & 41.4 & 80.5 & 5.6 & 5.5 \\
\hline CV (\%) & 9.6 & 5.7 & 10.7 & 7.1 & 6.7 & 5.4 & 4.4 & 5.8 \\
\hline
\end{tabular}

Notes: Numbers in the same column followed by similar letters did not significantly different based on Duncan Multiple range Test at 0.05 probability; CV: coefficient of variation; DAS: days after sowing; *) $1=$ highly resistant, $2-3=$ resistant, $4-5=$ moderately resistant, $6-7=$ susceptible, and $8-9=$ highly susceptible [5]

Both fresh and dry seeds of all promising lines (GH 1 to GH 10) together with check cultivars Kancil and Garuda Biga gave various responses to $A$. flavus infection. The infection of A. flavus on fresh seeds varied from $1.3-8.3 \%$ and that of $0.33-5.7 \%$ on dry seeds. All promising lines had lower number of seeds infected by A. flavus compared to the level of infection of check cultivar Garuda Biga. In general, the infection rate of dry seeds was lower than those of fresh seeds of all genotypes (Table 4). The success of drying up the pods as one of post-harvest management on reducing the level of $A$. flavus infection was supported by the work done [14] who reported a 13-58\% reduction of kernel infection. Genotype GH 6 had low infection rate and it was similar to those of genotype GH 3, GH 4, GH8, and check cultivar Kancil (Table 4). Peanut grains are sensitive to A. flavus infection. This fungus produces secondary metabolite called aflatoxin. Toxin that responsible for liver cancer once accumulates in the liver. 
Very dry $(<10 \%$ of MC) of newly harvested seeds of all genotypes gave lower level of aflatoxin contamination i.e., $<0.5 \mu \mathrm{g} / \mathrm{kg}$ (Table 4). Whilst aflatoxin contamination of the same dry pods of all genotypes after 3 months storage in the ambient room temperature gave the various levels of contamination. Genotype GH 6, GH 10, and GH 8 were consistently giving low aflatoxin contamination of $<0.5 \mu \mathrm{g} / \mathrm{kg}$. The contamination level of these three genotypes was significantly lower compared to those of check cultivars and other genotypes (Table 4). Based on the level of aflatoxin contamination after three months storage, all promising lines had less than $15 \mu \mathrm{g} / \mathrm{kg}$ that is the maximum of allowable level for human consumption [15].

Table 4. Aspergillus flavus infection and aflatoxin contamination on ten promising lines and two check cultivars in Muneng Research Station.

\begin{tabular}{|c|c|c|c|c|}
\hline \multirow[b]{2}{*}{ Code } & \multicolumn{2}{|c|}{ Aspergillus flavus infection (\%) } & \multicolumn{2}{|c|}{ Aflatoxin contamination $(\mu \mathrm{g} / \mathrm{kg})$} \\
\hline & $\begin{array}{c}\text { Fresh seeds } \\
( \pm 35 \% \text { moisture } \\
\text { content })\end{array}$ & $\begin{array}{c}\text { Dried seeds } \\
( \pm 10 \% \\
\text { moisture } \\
\text { content })\end{array}$ & $\begin{array}{c}\text { Fresh seeds } \\
(\mu \mathrm{g} / \mathbf{k g}) *)\end{array}$ & $\begin{array}{c}\text { After } 3 \text { months } \\
\text { storage } \\
(\mu \mathrm{g} / \mathrm{kg}) *)\end{array}$ \\
\hline GH 1 & 5.00 & 1.00 & $<0.5$ & 18.18 \\
\hline GH 2 & 2.00 & 0.67 & $<0.5$ & 3.5 \\
\hline GH 3 & 1.30 & 1.00 & $<0.5$ & 9.09 \\
\hline $\mathrm{GH} 4$ & 1.33 & 0.33 & $<0.5$ & 27.28 \\
\hline GH 5 & 2.33 & 1.00 & $<0.5$ & 5.5 \\
\hline GH 6 & 1.71 & 0.67 & $<0.5$ & $<0.5$ \\
\hline GH 7 & 3.33 & 0.67 & $<0.5$ & 4.5 \\
\hline GH 8 & 1.33 & 1.67 & $<0.5$ & $<0.5$ \\
\hline GH 9 & 2.33 & 3.33 & $<0.5$ & 27.27 \\
\hline GH 10 & 2.00 & 1.00 & $<0.5$ & $<0.5$ \\
\hline Kancil & 1.67 & 1.30 & $<0.5$ & 18.18 \\
\hline Garuda Biga & 8.3 & 5.7 & $<0.5$ & 8.5 \\
\hline
\end{tabular}

*) highly resistant: $<15 \%$ seed infection, moderately resistant: $15-30 \%$ infestion, moderately susceptible: $30-50 \%$, highly susceptible: $>50 \%[16]$.

\section{Conclusion}

The pod yield of ten peanut promising lines was higher than the two check cultivars; with the yield average is $2.855 \mathrm{tha}^{-1}$ for promising lines instead of $2.415 \mathrm{t} \mathrm{ha}^{-1}$ for the check cultivars. Despite highest pod yield of $3.09 \mathrm{t} \mathrm{ha}^{-1}$, GH 7 (G/GH502-00B-600-42-226-19) had higher score of foliar diseases and Aspergillus flavus infection than those of the check cultivars. Meanwhile GH 8 (MH/IC91278-99C-180-13-74) and GH 6 (LM/IC 87123-93-B-32) with pod yields of $2.91 \mathrm{t}$ and $2.84 \mathrm{tha}^{-1}$ had lower score of leafspots and/or rust, lower Aspergillus flavus infection and low aflatoxin contamination than those of check cultivars. Furthermore, GH 6 (LM/IC 87123-93-B-32) and GH 8 (MH/IC91278-99C-180-13-74) consistently had very low aflatoxin contamination of $<0.5 \mu \mathrm{gkg}^{-1}$ both at harvesting time and 3 months after storage. MH/IC91278-99C-180-13-74 and LM/IC 87123-93-B-32 therefore were appropriate to be promoted as new cultivars with high pod yield, resistant to foliar disease and $A$. flavus, and low aflatoxin contamination.

Acknowledgement. The authors extend the gratitude to the Indonesian Agency for Agricultural Research and Development (IAARD), the Ministry of Agriculture for funding the research. 


\section{References}

1. P. Janila, M. T. Variath, M. K. Pandey, H. Desmae, B. N. Motagi, P. Okori, S. S. Manohar, A. L. Rathnakumar, T. Radhakrishnan, B. Liao, R. K. Varshney, Frontiers in Plant Science 7, 289 (2016)

2. H. Demae, P. Janila, P. Okori, M. K. Pandey, B. N. Motagi, E. Monyo, O. Mponda, D. Okello, D. Sako, C. Echeckwu, R. Oteng-Frimponmg, A. Miningou, C. Ojiwo, R. K. Varshney, Plant Breeding 138, 425 (2019)

3. S.N. Nigam, F. Waliyar, R. Aruna, S.V. Reddy, P. Lava Kumar, P.Q. Craufurd, A.T. Diallo, B.R. Ntare, H.D. Upadhyaya, Peanut Science 36, 42 (2009)

4. J Purnomo, N. Nugrahaeni, Y Baliadi, Buletin Palawija 17, 102 (2019)

5. P. Subrahmanyam, D. McDonald, F. Waliyar, L. J. Reddy, S. N. Nigam, R. W. Gibbons, V. Ramanatha Rao, A. K. Singh, S. Pande, P. M. Reddy, P. V. Subba Rao, Information Bulletin No. 47. ICRISAT, India (1995)

6. M. A. Caulibaly, B. R. Ntare, V. E. Gracen, E. Y. Danquah, K. Ofori, A. S. Mahamane, International Journal of Innovative Science, Engineering \& Technology 4, 238 (2017)

7. R. K. Mathur, P. K. Ghosh, P. Manivel, Internat. J. Agric. Sci. 3, 15 (2007).

8. S. N. Nigam, http://oar.icrisat.org/8455/1/Groundnut $\% 20$ at $\% 20 a \% 20$ Glance.pdf, (2014)

9. E. Yol, S. Furat, H. D. Upadyaya, B. Uzun, Journal of Integrated Agriculture 17, 63 (2018)

10. A. A. Rahmianna, A. Wijanarko, J. Purnomo, Y. Baliadi, Biodiversitas 21, 5747 (2020)

11. S. N. Nayak, V. Hebbal, P. Bharati, H. L. Nadaf, G. K. Naidu, R. S. Bhat, Frontiers in Nutrition, 7 Article 45 (2020)

12. S. Nurhalimah, Y. Wahyu, S. Nurhidayah, E. Firmansyah, Journal of Tropical Crop Science 7, 22 (2021).

13. Y. Wahyu, D. R. Budiman, Buletin Agrohorti 1, 45 (2013)

14. V. Parimi, V. K. K. Kotamraju, H. K. Sudini, Agronomy 8, 10 (2018).

15. The National Standardization Agency of Indonesia [BSN], Maximum Limit of Mycotoxin in Foods (SNI 7385: 2009), in The National Standardization Agency of Indonesia, Jakarta, Indonesia (2009).

16. L. Siulin, L. Xuanqiang, L. Shaoxion, International Arachis Newsletter 16, 11 (1996) 